\title{
Reforming of Ethanol to Produce Hydrogen over PtRuMg/ZrO 2 Catalyst
}

\author{
Josh Y. Z. Chiou, ${ }^{1}$ Chi-Han Wang, ${ }^{1}$ Shih-Yi Yang, ${ }^{1}$ Jia-Lin Bi, ${ }^{1}$ \\ Chia-Chieh Shen, ${ }^{2,3,4}$ and Chen-Bin Wang ${ }^{1}$ \\ ${ }^{1}$ Department of Chemical and Materials Engineering, Chung Cheng Institute of Technology, National Defense University, \\ Tahsi, Taoyuan 33509, Taiwan \\ ${ }^{2}$ Fuel Cell Center, Yuan Ze University, Taoyuan 32003, Taiwan \\ ${ }^{3}$ Department of Mechanical Engineering, Yuan Ze University, Taoyuan 32003, Taiwan \\ ${ }^{4}$ Graduate School of Renewable Energy and Engineering, Yuan Ze University, Taoyuan 32003, Taiwan
}

Correspondence should be addressed to Chen-Bin Wang, chenbinwang@gmail.com

Received 15 March 2012; Accepted 24 April 2012

Academic Editor: Shrikrishna D. Sartale

Copyright (c) 2012 Josh Y. Z. Chiou et al. This is an open access article distributed under the Creative Commons Attribution License, which permits unrestricted use, distribution, and reproduction in any medium, provided the original work is properly cited.

\begin{abstract}
A modified $\mathrm{PtRu} / \mathrm{ZrO}_{2}$ catalyst with $\mathrm{Mg}$ is evaluated for the oxidative steam reforming of ethanol (OSRE) and the steam reforming of ethanol (SRE). In order to understand the variation in the reaction mechanism on OSRE and SRE, further analysis of both fresh and used catalyst is concentrated on for TEM, TG, Raman, and TPR characterization. The results show that the OSRE reaction requires a higher temperature $\left(T_{R} \sim 390^{\circ} \mathrm{C}\right)$ to achieve $100 \%$ ethanol conversion than the SRE reaction $\left(T_{R} \sim 2500^{\circ} \mathrm{C}\right)$. The distribution of CO is minor for both reactions ( $<5 \%$ for OSRE, $<1 \%$ for SRE). This demonstrates that the water gas shift (WGS) reaction is an important side-reaction in the reforming of ethanol to produce $\mathrm{H}_{2}$ and $\mathrm{CO}_{2}$. A comparison of the temperature of WGS ( $T_{\mathrm{WGS}}$ ) shows it is lower for the SRE reaction ( $T_{\mathrm{WGS}} \sim 250^{\circ} \mathrm{C}$ for SRE, $\sim 340^{\circ} \mathrm{C}$ for OSRE).
\end{abstract}

\section{Introduction}

The prospect of global energy shortages as well as increasingly stringent emission regulations has stimulated interest in renewable energies. Production of hydrogen from renewable sources derived from agricultural or other waste streams offers the possibility of lower or even no net greenhouse gas emissions [1, 2]. Among the candidates for hydrogen production, ethanol produced by the fermentation of biomass offers many advantages, such as low toxicity, high biodegradability, and easy transport [3-5]; thus, the reforming of ethanol is seen as a promising method for hydrogen production from renewable resource $[6,7]$. Hydrogen can be produced from ethanol through different reforming processes, for example, steam reforming of ethanol (SRE), partial oxidation of ethanol (POE), and oxidative steam reforming of ethanol (OSRE). Moreover, a high yield of hydrogen can be obtained from the SRE reaction [4-14].
The nature of the metal and its support strongly affect both stability and products distribution $[5,15]$. In view of the $\mathrm{ZrO}_{2}$-supported system, noble metal catalysts such as $\mathrm{Pt}$ and $\mathrm{Ru}$ are well known for their high catalytic activities, which have been extensively investigated. The sizeselective capability of $\mathrm{Pt} / \mathrm{ZrO}_{2}$ catalysts on the catalytic decomposition of alcohol for the production of hydrogen was reported by Cuenya's group [7, 16]. However, this catalyst deactivated at high temperatures due to carbon deposition. De Lima et al. [17] reported that the sideproducts of acetaldehyde and ethane were favored on $\mathrm{Pt} / \mathrm{ZrO}_{2}$ in the SRE. Relatively low reaction temperatures around 100 to $200^{\circ} \mathrm{C}$ in the POE and OSRE over a $\mathrm{Pt} / \mathrm{ZrO}_{2}$ and $\mathrm{PtRu} / \mathrm{ZrO}_{2}$ catalysts were reported by our previous studies [18-21], and $300^{\circ} \mathrm{C}$ was reported by Mattos and Noronha [22] in the POE reaction. The main problem found when using these catalysts is deactivation by sintering and carbon deposition. The use of basic oxides as supports and the addition of metal species ( $\mathrm{Li}, \mathrm{Na}, \mathrm{K}$, and $\mathrm{Cu}$, etc.) have 
been found to improve catalytic performance and overcome the disadvantages [9,23-25]. Recently, Carrero et al. [26] reported the effect of alkaline earth metals over $\mathrm{Cu}-\mathrm{Ni} / \mathrm{SiO}_{2}$ catalysts where a high hydrogen selectivity was obtained with $\mathrm{Mg}$, while the incorporation of Ca reduced coke formation.

Therefore, the main objective of this paper is to study $\mathrm{PtRuMg} / \mathrm{ZrO} \mathrm{O}_{2}$ catalyst for the SRE and OSRE reactions to produce hydrogen at a temperature lower than $300^{\circ} \mathrm{C}$ with higher ethanol conversion $\left(X_{\mathrm{EtOH}}\right)$, hydrogen yield $\left(Y_{\mathrm{H}_{2}}\right)$, and lower $\mathrm{CO}$ distribution. The expectation is that the catalytic activity and stability against the coke deposition of the PtRuMg/ZrO ${ }_{2}$ catalyst on the reforming of ethanol could be enhanced. The characterization of fresh and used catalysts was analyzed by TEM, TG, Raman, and TPR characterization.

\section{Experimental}

2.1. Catalyst Preparation. A sol-gel method was used for the preparation of the $\mathrm{ZrO}_{2}$ support using $\mathrm{Zr}\left[\mathrm{O}\left(\mathrm{CH}_{2}\right)_{3} \mathrm{CH}_{3}\right]_{4}$ (Strem) as the precursor. The PtRuMg/ZrO ${ }_{2}$ catalyst was prepared by the method of sequent incipient wetness impregnation using $\mathrm{H}_{2} \mathrm{PtCl}_{6}$ and $\mathrm{RuCl}_{3}$ as precursors $(1.5 \mathrm{wt} \%$ for each component) first to disperse on the $\mathrm{ZrO}_{2}$. After drying at $110^{\circ} \mathrm{C}$ and calcination at $400^{\circ} \mathrm{C}$ for $4 \mathrm{~h}, 1.0 \mathrm{wt} \%$ of $\mathrm{Mg}\left(\mathrm{NO}_{3}\right)_{2} \cdot 6 \mathrm{H}_{2} \mathrm{O}$ was incipient sequentially. After drying at $110^{\circ} \mathrm{C}$, the prepared sample was crashed to $60 \sim 80$ mesh and stored as fresh catalyst (labeled as $\mathrm{PtRuMg} / \mathrm{ZrO}_{2}$ ).

2.2. Catalyst Characterization. Transmission electron micrographs (TEMs) were taken on a PHILIPS (CM-200) microscope at an accelerated voltage of $200 \mathrm{kV}$. Thermal gravimetric analysis was carried out using a Seiko SSC5000 TG system. The rate of heating was maintained at $10^{\circ} \mathrm{C} \cdot \mathrm{min}^{-1}$. The measurement was carried from RT to $1000^{\circ} \mathrm{C}$ under air flowing with a rate of $100 \mathrm{~mL} \cdot \mathrm{min}^{-1}$. The measurements of the Raman spectroscopy were recorded using a Nicolet Almega XR Dispersive Raman spectrometer. The spectra were collected between 500 and $2000 \mathrm{~cm}^{-1}$, using the beam of a diode laser $(780 \mathrm{~nm})$, with the sample exposed to the air under ambient conditions. Reduction behavior was studied by temperature-programmed reduction (TPR). A sample of about $50 \mathrm{mg}$ was introduced a flow of $10 \% \mathrm{H}_{2} / \mathrm{N}_{2}$ gas mixture at a flow rate of $10 \mathrm{~mL} \cdot \mathrm{min}^{-1}$. During TPR, the temperature was increased at $7^{\circ} \mathrm{C} \cdot \mathrm{min}^{-1}$ from room temperature to $900^{\circ} \mathrm{C}$.

2.3. Catalytic Activity Measurement. Catalytic activities of the prepared sample towards the SRE and OSRE reactions were tested in a fixed-bed flow reactor at atmospheric pressure. Catalyst in the amount of $100 \mathrm{mg}$ was placed in a $4 \mathrm{~mm}$ i.d. quartz tubular reactor and held by glass-wool plugs. Before the reaction, the catalyst was activated by reduction with hydrogen at $300^{\circ} \mathrm{C}$ for $3 \mathrm{~h}$. The gas hourly space velocity (GHSV) was maintained at $22,000 \mathrm{~h}^{-1}$, and the $\mathrm{H}_{2} \mathrm{O} / \mathrm{EtOH}$ molar ratio was $13\left(\mathrm{H}_{2} \mathrm{O}: \mathrm{EtOH}=80: 20\right.$ by volume) for the SRE reaction; while the GHSV was maintained at $56,000 \mathrm{~h}^{-1}$, the $\mathrm{O}_{2} / \mathrm{EtOH}$ molar ratio was

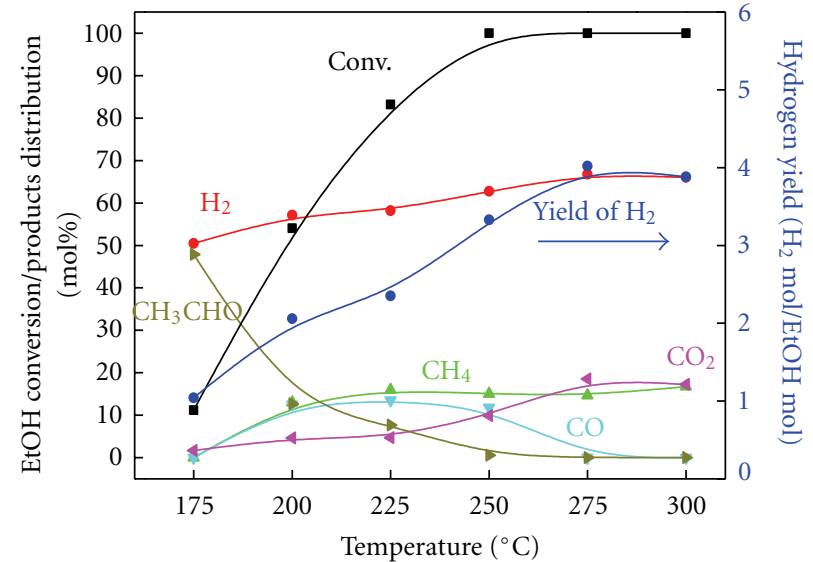

FIGURE 1: Catalytic performance in the SRE reaction over $\mathrm{PtRuMg} / \mathrm{ZrO}_{2}$ catalyst.

0.26 , and the $\mathrm{H}_{2} \mathrm{O} / \mathrm{EtOH}$ molar ratio was 4.86 for the OSRE reaction. A $5 \mathrm{~h}$ time-on-stream tests were maintained at each measured temperature. The analysis of the reactants and all reaction products was carried out online by gas chromatography, with columns of Porapak Q and Molecular Sieve $5 \mathrm{~A}$ for separation. The evaluation of the catalytic activity depended on the conversion, products distribution, and the yield of hydrogen:

$$
\begin{gathered}
X_{\mathrm{EtOH}}=\frac{\left(n_{\mathrm{EtOH}-\mathrm{in}}-n_{\mathrm{EtOH}-\mathrm{out}}\right)}{n_{\mathrm{EtOH}-\mathrm{in}}} \times 100 \%, \\
Y_{\mathrm{H}_{2}}=\frac{n_{\mathrm{H}_{2} \text {-out }}}{n_{\mathrm{EtOH}-\mathrm{in}}}, \\
S_{i}=\frac{n P_{i}}{n \sum P_{i}} \times 100 \%
\end{gathered}
$$

where $X_{\mathrm{EtOH}}$ is the conversion of ethanol, $Y_{\mathrm{H}_{2}}$ is the yield of hydrogen, $S_{i}$ is the distribution of different products, $P_{i}$ is the different products, and $n$ is the amounts of moles.

\section{Results and Discussion}

3.1. Catalytic Evaluation. Figure 1 illustrates the $X_{\mathrm{EtOH}}$, products distribution (water excluded), and $Y_{\mathrm{H}_{2}}$ from SRE with an $\mathrm{H}_{2} \mathrm{O} / \mathrm{EtOH}$ molar ratio of 13 over the PtRuMg/ZrO catalyst between 175 and $300^{\circ} \mathrm{C}$. About $1 \mathrm{~h}$ to reach the steady state and the recorded date was $5 \mathrm{~h}$ time-on-stream tests at each reaction temperature. The concentration of hydrogen increased progressively with increases in temperature $\left(T_{R}\right)$. The detailed proposed pathway was shown in the Scheme 1. Below $200^{\circ} \mathrm{C}$, the main product besides hydrogen was acetaldehyde, thus indicating that it behaved as a dehydrogenation of ethanol, and then acetaldehyde decomposition into methane and $\mathrm{CO}$ with increasing temperature. This indicated that both platinum and ruthenium had a stronger 


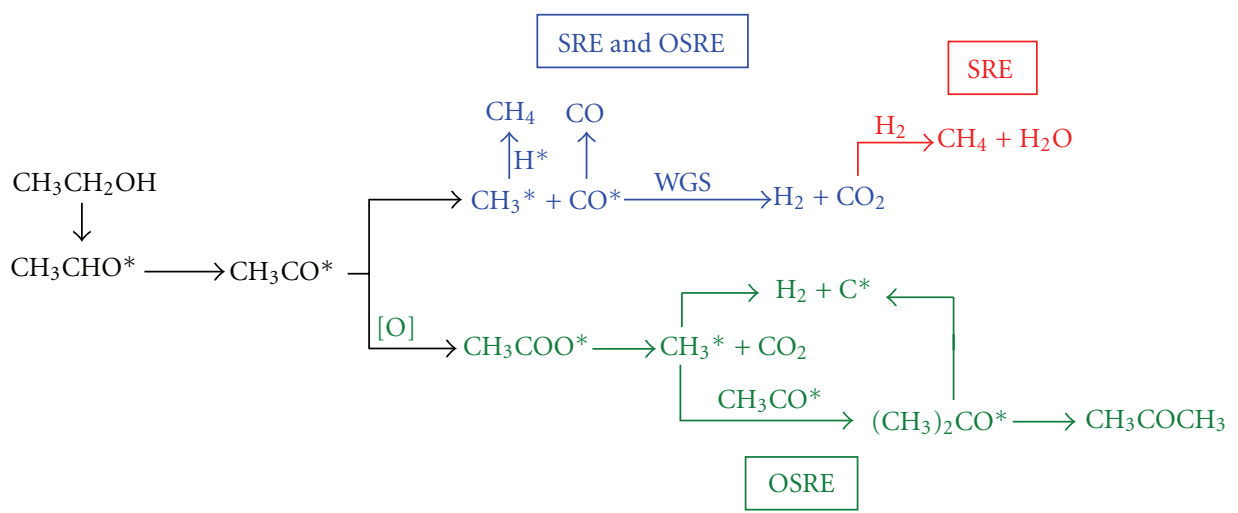

Scheme 1: Reaction routes of SRE and OSRE over PtRuMg/ZrO $\mathrm{rO}_{2}$ catalyst.

capacity for breaking the $\mathrm{C}-\mathrm{C}$ bond in the reforming of ethanol

$$
\begin{gathered}
\mathrm{C}_{2} \mathrm{H}_{5} \mathrm{OH} \longrightarrow \mathrm{CH}_{3} \mathrm{CHO}+\mathrm{H}_{2} \\
\mathrm{CH}_{3} \mathrm{CHO} \longrightarrow \mathrm{CH}_{4}+\mathrm{CO} .
\end{gathered}
$$

At higher temperatures $\left(T_{R}>225^{\circ} \mathrm{C}\right)$, concentrations of $\mathrm{CO}_{2}$ up to $18 \%$ accompanied the decreasing of $\mathrm{CO}$ to $0.2 \%$. At the same time, the concentration of methane through the decomposition of acetaldehyde was significant. This indicated that the water-gas shift (WGS) reaction occurred at a lower temperature than that of the cobalt oxide [12] and the $\mathrm{PtRu} / \mathrm{ZrO}_{2}$ catalyst [20]. This showed that the addition of magnesium improved the reforming activities and enhanced the WGS reaction at lower temperatures

$$
\mathrm{CO}+\mathrm{H}_{2} \mathrm{O} \longrightarrow \mathrm{H}_{2}+\mathrm{CO}_{2} .
$$

When the $T_{R}$ increased to $280^{\circ} \mathrm{C}$, the amount of $\mathrm{CH}_{4}$ sideproduct increased slightly to approach $16 \%$ and decreased the yield of hydrogen since the reversed water-gas shift reaction (RWGS) occurred. The maximum $Y_{\mathrm{H}_{2}}$ approached 4.0 around $275^{\circ} \mathrm{C}$ for the SRE reaction

$$
\mathrm{CO}_{2}+4 \mathrm{H}_{2} \longrightarrow \mathrm{CH}_{4}+2 \mathrm{H}_{2} \mathrm{O} .
$$

Figure 2 displays the $X_{\mathrm{EtOH}}$, products distribution (water excluded), and $Y_{\mathrm{H}_{2}}$ from OSRE with an $\mathrm{EtOH} / \mathrm{H}_{2} \mathrm{O} / \mathrm{O}_{2}$ at a molar ratio of $1: 4.86: 0.26$ over a PtRuMg/ZrO 2 catalyst between 250 and $420^{\circ} \mathrm{C}$. As compared with the SRE reaction, there were significant differences in the different reactions. The SRE reaction preceded complete conversion of the ethanol at $250^{\circ} \mathrm{C}$, while there was only $75 \%$ conversion at this temperature and full ethanol conversion exceeded $390^{\circ} \mathrm{C}$ for the OSRE reaction. The temperature for the decomposition of acetaldehyde $\left(D_{T}\right)$ showed that the easy cracking promoted the formation of hydrogen. The $D_{T}$ on the SRE reaction approached $200^{\circ} \mathrm{C}$, and above $250^{\circ} \mathrm{C}$ for the OSRE reaction. The acetaldehyde disappeared at $275^{\circ} \mathrm{C}$ for the SRE reaction, and at $420^{\circ} \mathrm{C}$ for the OSRE reaction. A comparison of the temperature of WGS ( $T_{\mathrm{WGS}}$ ) showed that it was lower for the SRE reaction $\left(T_{\mathrm{WGS}} \sim 250^{\circ} \mathrm{C}\right.$ for SRE, $\sim 340^{\circ} \mathrm{C}$ for OSRE). The distribution of $\mathrm{CO}$ was

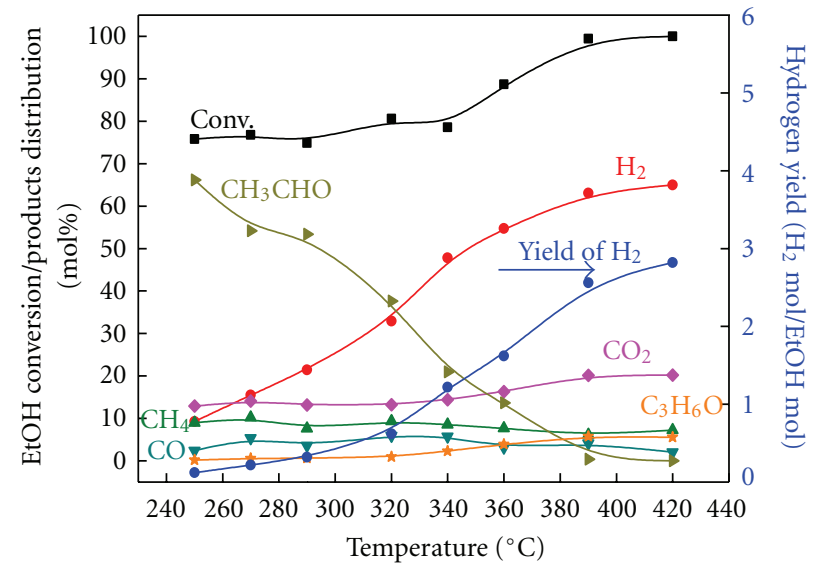

FIGURE 2: Catalytic performances in the OSRE reaction over $\mathrm{PtRuMg} / \mathrm{ZrO}_{2}$ catalyst.

minor for both reactions ( $<5 \%$ for OSRE, $<0.5 \%$ for SRE). Besides the main products of $\mathrm{H}_{2}$ and $\mathrm{CO}_{2}$, the decreasing of acetaldehyde accompanied with the trace amounts of acetone was produced through the condensation of acetaldehyde (showed in the Scheme 1) at $T_{R}>340^{\circ} \mathrm{C}$. At a further temperature increase, the acetone was still detected. This clearly influenced the yield of hydrogen and also, possibly, the coke deposition. The maximum $Y_{\mathrm{H}_{2}}$ only approached 2.8 around $420^{\circ} \mathrm{C}$ for the OSRE reaction.

3.2. Characterization of Used Catalyst. The design of a stable and applicable catalyst is one of the most important issues in the production of hydrogen from ethanol. The significant deactivation reported for hydrogen production from ethanol reforming is usually attributed to carbon formation and sintering of active metals, which is strongly influenced by the nature of the support, catalyst, and reaction conditions (especially temperature and $\mathrm{H}_{2} \mathrm{O} / \mathrm{EtOH} / \mathrm{O}_{2}$ ratio) $[9,27-29]$. In order to obtain more information about the behavior of the used catalyst, TEM, TG, Raman, and TPR characterizations were pursued for the samples after the SRE and OSRE catalytic tests. 


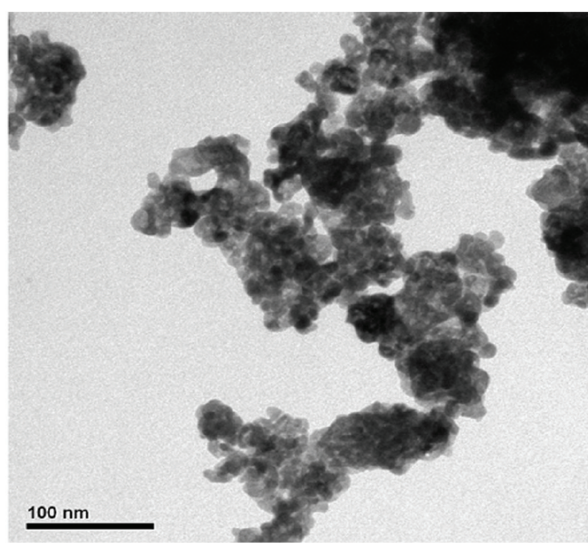

(a)

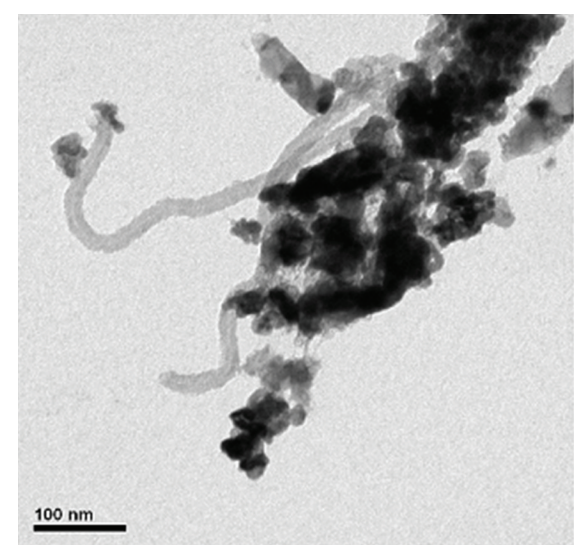

(b)

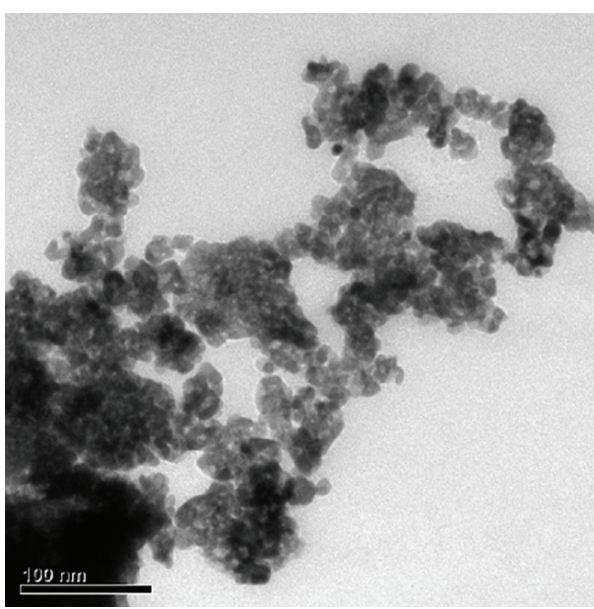

(c)

Figure 3: TEM images of fresh and used catalysts: (a) fresh, (b) after OSRE reaction, and (c) after SRE reaction.

Figure 3 shows the TEM micrographs of both fresh and used catalysts. A comparison with the fresh sample (see Figure 3(a)) showed an apparent deposition of coke on the used catalyst after the OSRE reaction (see Figure 3(b)). There was no obvious coke formation observed after the SRE reaction (see Figure 3(c)). The specific weight loss of combustion of

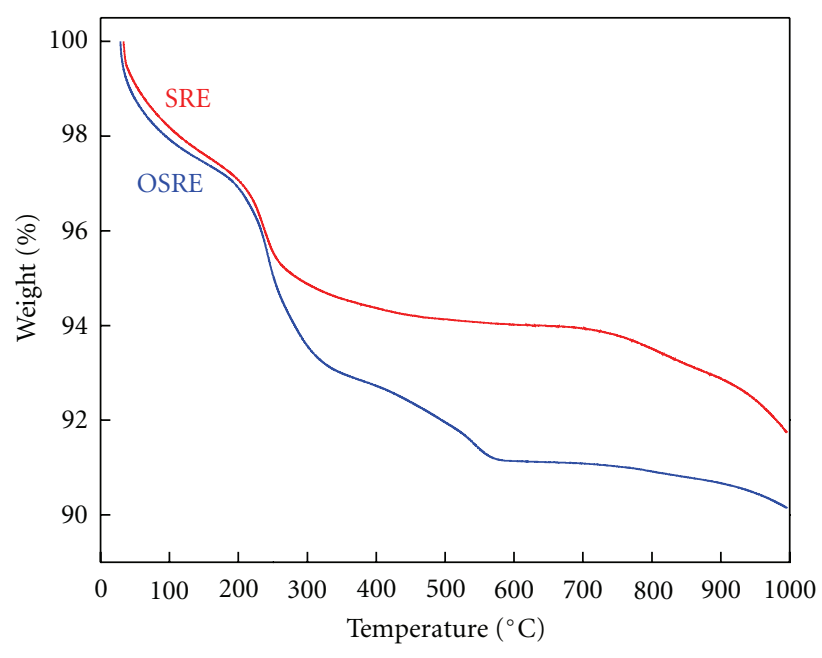

FIGURE 4: TG curves of used catalyst after SRE and OSRE reaction.

adsorbed $\mathrm{C}_{1}$ species $\left(200 \sim 300^{\circ} \mathrm{C}\right)$ and coke $\left(400 \sim 600^{\circ} \mathrm{C}\right)$ on the catalyst surface was obtained from the TG results (see Figure 4). Since the addition of magnesium modified the catalyst becomes slightly base which may be adsorbed $\mathrm{C}_{1}$ species after the reforming reaction. It was apparent that only after the OSRE reaction was the combustion of coke observed. Furthermore, the Raman spectra (see Figure 5) of the used catalyst after the SRE reaction differed from the OSRE reaction. There were two bands centered at 1320 (D-band) and 1590 (G-band) $\mathrm{cm}^{-1}$, characteristic of poorly ordered carbon deposition [30], observed after the OSRE reaction but not after the SRE reaction. This result indicated that the coke formed through the OSRE reaction. Also, the evidence of coke formation can be demonstrated by the TPR analysis. Figure 6 shows the TPR profiles of the used catalyst after the SRE and OSRE reactions. Two reduction regions can be distinguished: one region for the adsorbed $\mathrm{C}_{1}$ species (around $298^{\circ} \mathrm{C}$ ) and the other region for coke (around $584^{\circ} \mathrm{C}$ ), with the broad signal coming from the methanation of deposited carbon [8]

$$
\mathrm{C}+2 \mathrm{H}_{2} \longrightarrow \mathrm{CH}_{4} \text {. }
$$

From the characterization of the used catalyst, we observed a more pronounced coke formation in the OSRE reaction and confirmed that the designed PtRuMg/ZrO catalyst was a suitable application on the SRE reaction.

\section{Conclusions}

A novel and high performance PtRuMg/ZrO $\mathrm{Zr}_{2}$ catalyst had been designed and applied on the SRE and OSRE reaction to produce hydrogen at low temperature. The results showed that the distribution of $\mathrm{CO}$ was minor for both reactions ( $<5 \%$ for OSRE, $<1 \%$ for SRE). The OSRE reaction required a higher temperature $\left(T_{R} \sim 390^{\circ} \mathrm{C}\right)$ to achieve $100 \%$ ethanol conversion than the SRE reaction $\left(T_{R} \sim 250^{\circ} \mathrm{C}\right)$. Also the temperature of WGS accompanying the OSRE reaction was higher $\left(T_{\mathrm{WGS}} \sim 340^{\circ} \mathrm{C}\right)$ than that of the SRE reaction 


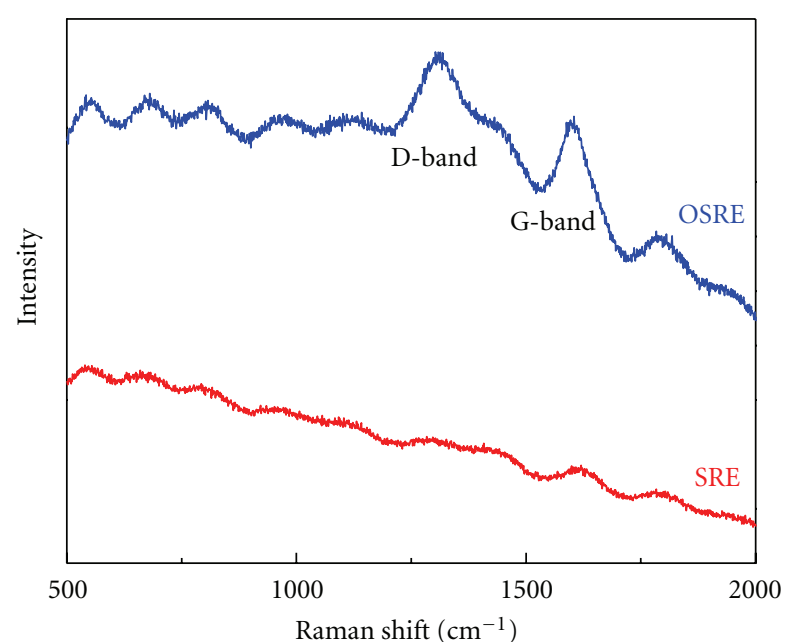

FIGURE 5: Raman spectra of used catalyst after SRE and OSRE reaction.

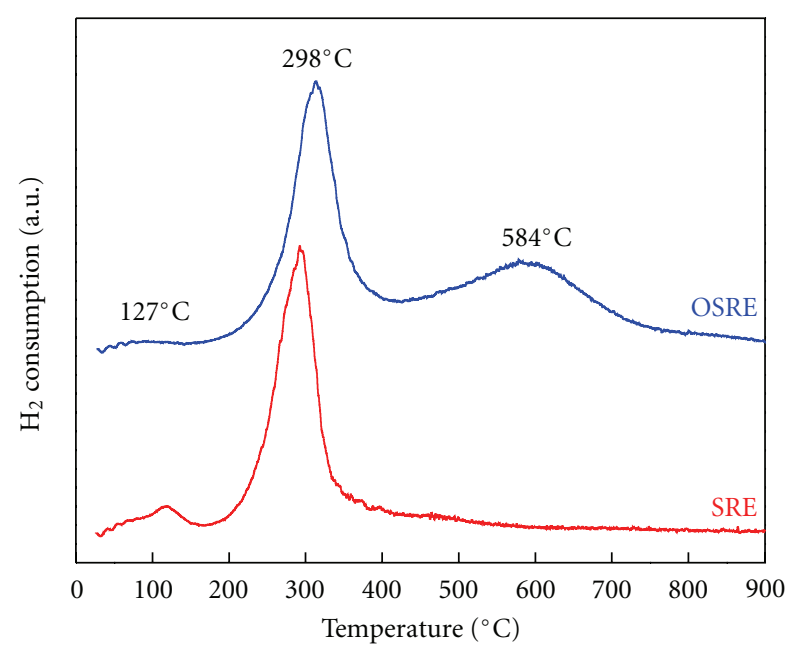

FIGURE 6: TPR profiles of used catalyst after SRE and OSRE reaction.

$\left(T_{\text {WGS }} \sim 250^{\circ} \mathrm{C}\right)$. A more pronounced coke formation was observed in the OSRE reaction. In considering the catalytic stability against the coke deposition, application of $\mathrm{PtRuMg} / \mathrm{ZrO}_{2}$ catalyst on the SRE reaction is suitable.

\section{Acknowledgment}

The authors are pleased to acknowledge the financial support for this study by the National Science Council of the Republic of China under contract nos. of NSC 99-2113-M-606-001MY3, and NSC 101-2623-E-155-001-ET.

\section{References}

[1] A. E. Farrell, R. J. Plevin, B. T. Turner, A. D. Jones, M. O’Hare, and D. M. Kammen, "Ethanol can contribute to energy and environmental goals," Science, vol. 311, no. 5760, pp. 506-508, 2006.
[2] B. E. Dale and D. Pimentel, "Two views on whether corn ethanol and, eventually, ethanol from cellulosic biomass will efficiently deliver national energy security," Chemical \& Engineering News, vol. 85, no. 51, pp. 12-16, 2007.

[3] Y. Liu, T. Hayakawa, T. Tsunoda et al., "Steam reforming of methanol over $\mathrm{Cu} / \mathrm{CeO}_{2}$ catalysts studied in comparison with $\mathrm{Cu} / \mathrm{ZnO}$ and $\mathrm{Cu} / \mathrm{Zn}(\mathrm{Al}) \mathrm{O}$ catalysts," Topics in Catalysis, vol. 22, no. 3-4, pp. 205-213, 2003.

[4] P. D. Vaidya and A. E. Rodrigues, "Insight into steam reforming of ethanol to produce hydrogen for fuel cells," Chemical Engineering Journal, vol. 117, no. 1, pp. 39-49, 2006.

[5] A. Haryanto, S. Fernando, N. Murali, and S. Adhikari, "Current status of hydrogen production techniques by steam reforming of ethanol: a review," Energy and Fuels, vol. 19, no. 5, pp. 2098-2106, 2005.

[6] H. Muroyama, R. Nakase, T. Matsui, and K. Eguchi, "Ethanol steam reforming over Ni-based spinel oxide," International Journal of Hydrogen Energy, vol. 35, no. 4, pp. 1575-1581, 2010.

[7] M. Ni, D. Y. C. Leung, and M. K. H. Leung, "A review on reforming bio-ethanol for hydrogen production," International Journal of Hydrogen Energy, vol. 32, no. 15, pp. 32383247, 2007.

[8] J. Llorca, N. Homs, J. Sales, and P. R. de la Piscina, "Efficient production of hydrogen over supported cobalt catalysts from ethanol steam reforming," Journal of Catalysis, vol. 209, no. 2, pp. 306-317, 2002.

[9] A. N. Fatsikostas and X. E. Verykios, "Reaction network of steam reforming of ethanol over Ni-based catalysts," Journal of Catalysis, vol. 225, no. 2, pp. 439-452, 2004.

[10] P. K. Cheekatamarla and C. M. Finnerty, "Reforming catalysts for hydrogen generation in fuel cell applications," Journal of Power Sources, vol. 160, no. 1, pp. 490-499, 2006.

[11] F. Frusteri, S. Freni, L. Spadaro et al., " $\mathrm{H}_{2}$ production for MC fuel cell by steam reforming of ethanol over $\mathrm{MgO}$ supported $\mathrm{Pd}, \mathrm{Rh}, \mathrm{Ni}$ and Co catalysts," Catalysis Communications, vol. 5, no. 10, pp. 611-615, 2004.

[12] C. B. Wang, C. C. Lee, J. L. Bi, J. Y. Siang, J. Y. Liu, and C. T. Yeh, "Study on the steam reforming of ethanol over cobalt oxides," Catalysis Today, vol. 146, no. 1-2, pp. 76-81, 2009.

[13] J. Y. Siang, C. C. Lee, C. H. Wang et al., "Hydrogen production from steam reforming of ethanol using a ceriasupported iridium catalyst: effect of different ceria supports," International Journal of Hydrogen Energy, vol. 35, no. 8, pp. 3456-3462, 2010.

[14] J. Y. Liu, C. C. Lee, C. H. Wang, C. T. Yeh, and C. B. Wang, "Application of nickel-lanthanum composite oxide on the steam reforming of ethanol to produce hydrogen," International Journal of Hydrogen Energy, vol. 35, no. 9, pp. 4069-4075, 2010.

[15] P. D. Vaidya and A. E. Rodrigues, "Kinetics of steam reforming of ethanol over a $\mathrm{Ru} / \mathrm{Al}_{2} \mathrm{O}_{3}$ catalyst," Industrial \& Engineering Chemistry Research, vol. 45, no. 19, pp. 6614-6618, 2006.

[16] J. R. Croy, S. Mostafa, J. Liu, Y. Sohn, H. Heinrich, and B. R. Cuenya, "Support dependence of $\mathrm{MeOH}$ decomposition over size-selected Pt nanoparticles," Catalysis Letters, vol. 119, no. 3-4, pp. 209-216, 2007.

[17] S. M. de Lima, A. M. Silva, I. O. da Cruz et al., " $\mathrm{H}_{2}$ production through steam reforming of ethanol over $\mathrm{Pt} / \mathrm{ZrO}_{2}, \mathrm{Pt} / \mathrm{CeO}_{2}$ and $\mathrm{Pt} / \mathrm{CeZrO}_{2}$ catalysts," Catalysis Today, vol. 138, no. 3-4, pp. 162-168, 2008.

[18] J. L. Bi, S. N. Hsu, C. T. Yeh, and C. B. Wang, "Lowtemperature mild partial oxidation of ethanol over supported 
platinum catalysts," Catalysis Today, vol. 129, no. 3, pp. 330335, 2008.

[19] S. N. Hsu, J. L. Bi, W. F. Wang, C. T. Yeh, and C. B. Wang, "Low-temperature partial oxidation of ethanol over supported platinum catalysts for hydrogen production," International Journal of Hydrogen Energy, vol. 33, no. 2, pp. 693-699, 2008.

[20] J. L. Bi, Y. Y. Hong, C. C. Lee, C. T. Yeh, and C. B. Wang, "Novel zirconia-supported catalysts for low-temperature oxidative steam reforming of ethanol," Catalysis Today, vol. 129, no. 3-4, pp. 322-329, 2007.

[21] C. H. Wang, K. F. Ho, and J. Y. Z. Chiou, "Oxidative steam reforming of ethanol over $\mathrm{PtRu} / \mathrm{ZrO}_{2}$ catalysts modified with sodium and magnesium," Catalysis Communications, vol. 12, no. 10, pp. 854-858, 2011.

[22] L. V. Mattos and F. B. Noronha, "Partial oxidation of ethanol on supported Pt catalysts," Journal of Power Sources, vol. 145, no. 1, pp. 10-15, 2005.

[23] A. J. Vizcaino, A. Carrero, and J. A. Calles, "Hydrogen production by ethanol steam reforming over $\mathrm{Cu}-\mathrm{Ni}$ supported catalysts," International Journal of Hydrogen Energy, vol. 32, no. 10-11, pp. 1450-1461, 2007.

[24] F. Frusteri, S. Freni, V. Chiodo et al., "Steam reforming of bio-ethanol on alkali-doped $\mathrm{Ni} / \mathrm{MgO}$ catalysts: hydrogen production for MC fuel cell," Applied Catalysis A, vol. 270, no. 1-2, pp. 1-7, 2004.

[25] J. Sun, X. P. Qiu, F. Wu, and W. T. Zhu, " $\mathrm{H}_{2}$ from steamreforming of ethanol at low temperature over $\mathrm{Ni} / \mathrm{Y}_{2} \mathrm{O}_{3}$, $\mathrm{Ni} / \mathrm{La}_{2} \mathrm{O}_{3}$ and $\mathrm{Ni} / \mathrm{Al}{ }_{2} \mathrm{O}_{3}$ catalysts for fuel-cell application," International Journal of Hydrogen Energy, vol. 30, no. 4, pp. 437-445, 2005.

[26] A. Carrero, J. A. Calles, and A. J. Vizcaino, "Effect of Mg and $\mathrm{Ca}$ addition on coke deposition over $\mathrm{Cu}-\mathrm{Ni} / \mathrm{SiO}_{2}$ catalysts for ethanol steam reforming," Chemical Engineering Journal, vol. 163, no. 3, pp. 395-402, 2010.

[27] A. N. Fatsikostas, D. I. Kondarides, and X. E. Verykios, "Production of hydrogen for fuel cells by reformation of biomass-derived ethanol," Catalysis Today, vol. 75, no. 1-4, pp. 145-155, 2002.

[28] L. F. de Mello, F. B. Noronha, and M. Schmal, "NO reduction with ethanol on $\mathrm{Pd}-\mathrm{Mo} / \mathrm{Al}_{2} \mathrm{O}_{3}$ catalysts," Journal of Catalysis, vol. 220, no. 2, pp. 358-371, 2003.

[29] M. A. Goula, S. K. Kontou, and P. E. Tsiakaras, "Hydrogen production by ethanol steam reforming over a commercial $\mathrm{Pd} / \gamma-\mathrm{Al}_{2} \mathrm{O}_{3}$ catalyst," Applied Catalysis B, vol. 49, no. 2, pp. 135-144, 2004.

[30] P. Lespade, A. Marchand, M. Couzi, and F. Cruege, "Caracterisation de materiaux carbones par microspectrometrie Raman," Carbon, vol. 22, no. 4-5, pp. 375-385, 1984. 

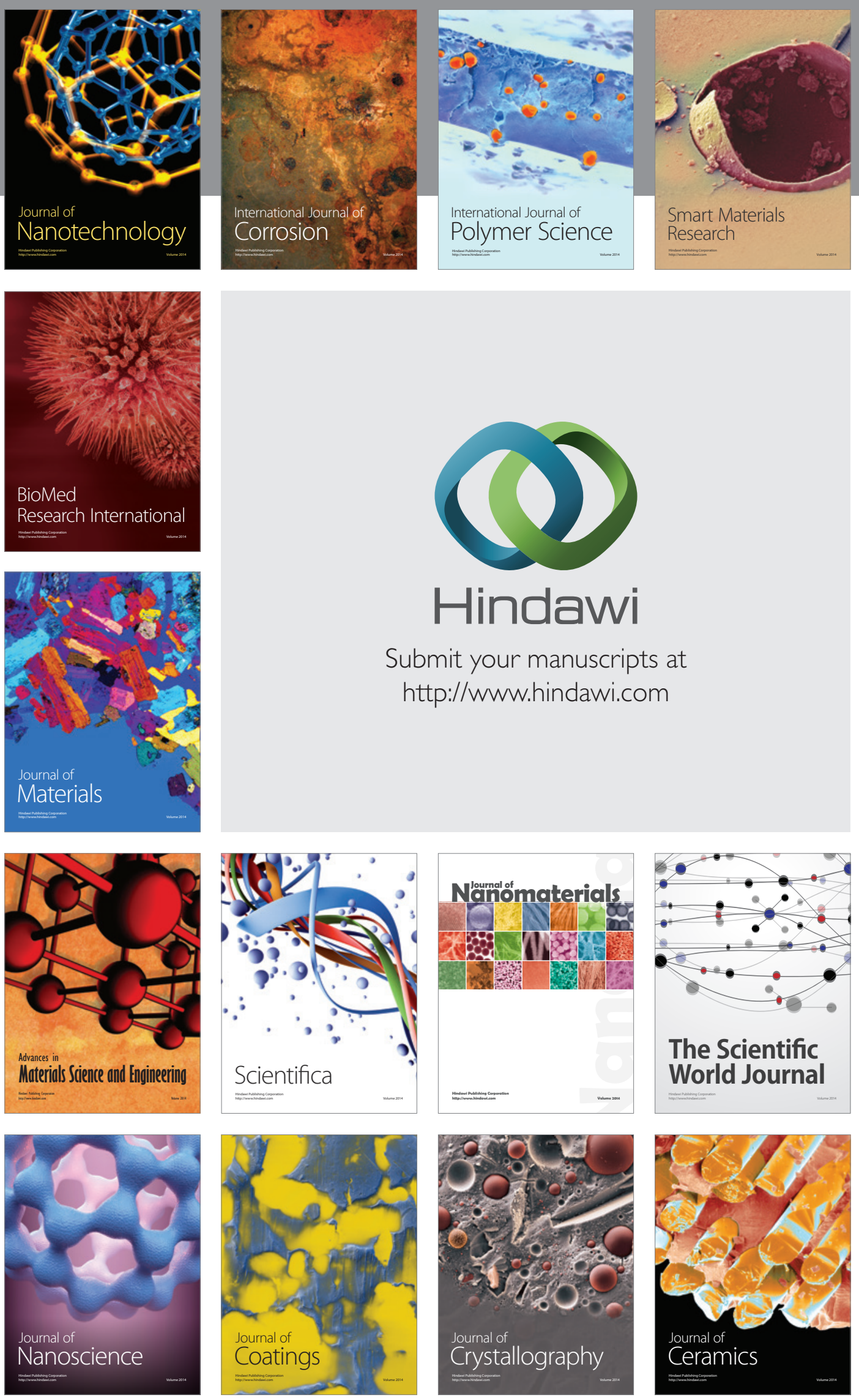

The Scientific World Journal

Submit your manuscripts at

http://www.hindawi.com

\section{World Journal}

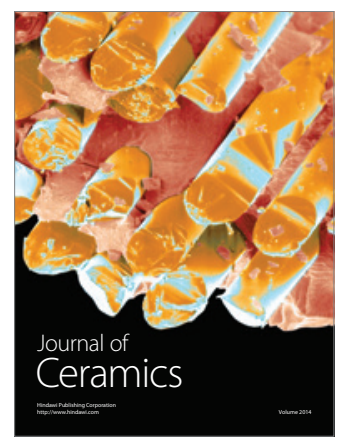

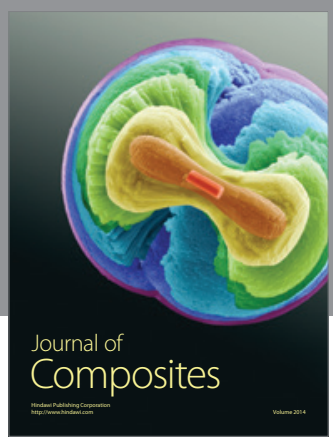
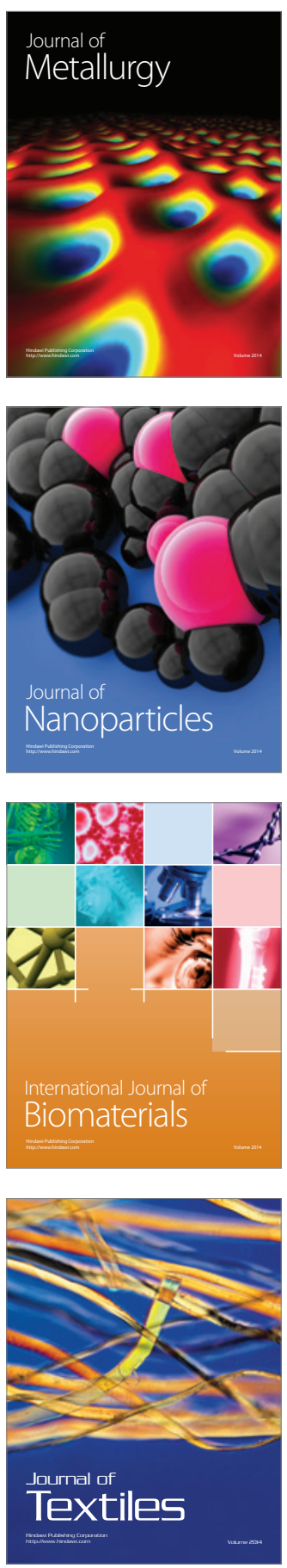